\title{
Effect of energy sources on the apparent total tract digestibility and excretion of nutrients by bovine cattle
}

\author{
Efecto de fuentes energéticas sobre la digestibilidad aparente total \\ y excreción de nutrientes por bovinos
}

\author{
Laura Romero S, ${ }^{1 *}$ M.Sc, Paulo HM Rodrigues, ${ }^{1}$ Ph.D, Carolina T Marino, ${ }^{1}$ Ph.D, \\ Lerner A Pinedo, ${ }^{1}$ Ph.D, Maurício F Martins, ${ }^{1}$ M.Sc, Eduardo CO Cassiano, ${ }^{1}$ M.Sc, \\ Flavio Perna Jr, ${ }^{1}$ M.Sc.
}

\begin{abstract}
${ }^{1}$ Universidade de São Paulo. Departamento de Nutrição e Produção Animal. Faculdade de Medicina Veterinária e Zootecnia. Campus de Pirassununga. Rua Duque de Caxias Norte, 225, Cep:13635-900. Pirassununga, SP. BRASIL. *Correspondencia: laurazootec@hotmail.com
\end{abstract}

Received: June 2013; Accepted: December 2013.

\begin{abstract}
Objective. To evaluate the effect of three energy sources on the intake, total apparent digestibility and excretion of nutrients in cattle diet. Materials and methods. Six ruminally cannulated cows $(730 \pm 70 \mathrm{~kg})$ were distributed into three treatments in a replicated $3 \times 3$ Latin square experimental design, where: (I) Control: Low ether extract diet (3.50\% EE); (II) Soybean: High ether extract diet $(5.30 \%$ EE) with inclusion of $15 \%$ soybean and (III) Citrus pulp: Low ether extract diet $(3.00 \%$ EE) and high pectin involvement with inclusion of $15 \%$ citrus pulp. To determine the digestibility of DM and its fractions, chromic oxide was used as a marker. Nutrient excretion was calculated from the digestibility coefficient of each fraction. Results. The soybean treatment reduced $(p<0.05)$ dry matter, crude protein, nitrogen-free extract and organic matter intake and increased ether extract intake. There was no effect ( $p>0.05$ ) of the energy source on the digestibility coefficients of DM, CP, NDF, EE, NFE or OM. The TDN value was higher for the soybean treatment. The excretion of DM, NFE and OM was lower $(p<0.05)$ for the soybean treatment. All energy sources influenced the excretion of crude protein. Conclusions. The energy sources used did not affect the digestibility of the diets and are indicated as high potential sources to be used in cattle.
\end{abstract}

Key words: Food consumption, Digestibility, Nutrients, Citrus pulp, Ruminants (Source: USDA).

\section{RESUMEN}

Objetivo. Evaluar el efecto de tres fuentes energéticas sobre el consumo, la digestibilidad aparente total y la excreción de nutrientes de la dieta en bovinos. Materiales y métodos. Seis vacas $(730 \pm 70 \mathrm{~kg})$ canuladas en rumen fueron distribuidas en tres tratamientos, en un diseño experimental cuadrado latino $3 \times 3$ replicado, a saber: (I) Control: Dieta de bajo extracto etéreo ( $3.50 \%$ de EE); (II) Soya: Dieta de alto extracto etéreo (5.30\% de EE) con inclusión de $15 \%$ de grano de soya y (III) Pulpa Cítrica: Dieta de bajo extracto etéreo ( $3.00 \%$ de EE) y alta participación de pectina con inclusión de $15 \%$ de pulpa cítrica. Para determinar la digestibilidad de la MS y sus fracciones, fue utilizado el marcador de óxido de cromo. La excreción de nutrientes, fue calculada a partir de los coeficientes de digestibilidad de cada fracción. Resultados. El tratamiento con soya redujo $(p<0.05)$ el consumo de materia seca, 
proteína bruta, extracto no nitrogenado y materia orgánica, de igual manera, incrementó el consumo de extracto etéreo. No no se observó efecto $(p>0.05)$ de fuente energética para los coeficientes de digestibilidad de la MS, PB, FDN, EE, ENN y MO. El valor de NDT fue mayor para el tratamiento con soya. La excreción de MS, ENN y MO fue menor $(p<0.05)$ para el tratamiento con soya. Todas las fuentes energéticas influyeron en la excreción de proteína bruta. Conclusiones. Las fuentes energéticas utilizadas, no afectaron la digestibilidad de las dietas, y estan indicadas como fuentes de elevado potencial en la alimentación de bovinos.

Palabras clave: Consumo de alimento, digestibilidad, nutrientes, pulpa cítrica, rumiantes (Fuente: USDA).

\section{INTRODUCTION}

Nutrient consumption and digestibility and their use in the different compartments of the digestive tract are estimated to be the closest approximation to the real nutritional value in food. The knowledge of the characteristics of food and its balance in the formulation of portions is a fundamental tool to meet animal needs, in order for them to express their genetic potential for production. Currently, there is variety of food that may be used in ruminant nutrition. Meanwhile, their nutritional value and quality are determined by the complex interaction between nutrients and the microorganisms in the digestive tract, digestive process, absorption, transport, and metabolite use, aside from the animal's own physiological condition (1). The search for alternative ingredients for ruminant nutrition leads to permanent investigation on the dynamics of fermentation and digestion of these ingredients, in processes related to production animal nutrition (2).

The digestibility coefficient of a diet is important to indicate the real available nutrients in food for the animal, aside from describing their nutritional value (3), since this shows how much food the microorganisms in the rumen actually use and expresses the capacity of the animal to use each nutrient in a higher or lower scale.

Regarding energy sources, such as citrus pulp and soybean pulp, they are characterized by their ability to alter the fermentative profile, which results in changes in the rumen environment, altering in a certain way the digestibility of some nutrients by rumen $\mathrm{pH}$ modulation, as a result of the short chain fatty acid proportion that is formed and the high fermentation speed.

Pectin fermentation in citrus pulp provides a higher $\mathrm{pH}$ in comparison to other diets with corn, fat or oils (4). Even though pectin is rapidly fermented in the rumen, it produces acetate as a final product, as occurs in cellulose fermentation. This way, replacing the sources of starch with citrus pulp may promote beneficial effects,

\section{INTRODUCCIÓN}

El consumo y digestibilidad de los nutrientes y la utilización de estos en los diferentes compartimientos del tracto digestivo son la estimativa que más se aproxima al valor nutritivo verdadero de los alimentos. El conocimiento de las características de los alimentos y su balance en la formulación de raciones, se torna una herramienta fundamental para suplir las necesidades de los animales, con el fin de que puedan expresar su potencial genético para la producción. En la actualidad existe una variedad de alimentos que pueden ser utilizados en la alimentación de rumiantes. Entre tanto, su valor nutricional y su calidad son determinados por la compleja interacción entre los nutrientes y los microorganismos del tracto digestivo en los procesos de digestión, absorción, transporte y utilización de metabolitos, además de la propia condición fisiológica del animal (1). La búsqueda de ingredientes alternativos para la nutrición de rumiantes lleva a constantes investigaciones de la dinámica de la fermentación y digestión de esos ingredientes, en procesos que están relacionados con la nutrición de animales de producción (2).

El coeficiente de digestibilidad de una dieta es importante por indicar que nutrientes de un alimento están realmente disponibles para el animal, además, de describir el valor nutritivo del mismo (3), puesto que refleja el aprovechamiento de cada alimento por los microorganismos del rumen y expresa la capacidad del animal para utilizar, en mayor o menor escala, cada nutriente.

Referente a fuentes energéticas, como la pulpa cítrica y el grano de soya, estas se caracterizan por alterar el perfil fermentativo, resultando en cambios en el ambiente ruminal, logrando, de cierta forma, alterar la digestibilidad de algunos nutrientes por la modulación del pH ruminal, como resultado de la proporción de los ácidos grasos de cadena corta formados y de la velocidad de la fermentación.

La fermentación de la pectina de la pulpa cítrica proporciona un $\mathrm{pH}$ más elevado en comparación a dietas con maíz o grasas y aceites (4). La pectina, a pesar de ser rápidamente fermentada en el 
mainly related to the ruminal environment, because of the buffer effect of pectin, resulting in better conditions for the digestibility of fiber in forage, when having diets rich in concentrates (5). On the other hand, fats and oils have been added to ruminant diets with the purpose of increasing the energetic concentration of the diet. However, one of the main setbacks with the use of fats in ruminant diets, specially, when they are unsaturated, is the negative effect on the consumption of dry matter and the reduction of fiber digestibility (5).

As previously mentioned, the nutritional evaluation of the animals feed is necessary to characterize their potential and use in ruminant diet formulation. This way, the purpose of this study was to evaluate the effect of three energetic sources on consumption, total apparent digestibility, and nutrient excretion in bovines.

\section{MATERIALS AND METHODS}

Animals and infrastructure. The experiment was undertaken at the Department of Animal Nutrition and Production, of the Faculty of Veterinary Medicine and Animal Husbandry of the Universidad de São Paulo, Brazil, at the facilities of the Experimental Barn and the Laboratory of Animal Nutrition and Bromatology.

Six non-pregnant and non-lactating cows were used, with an average live weight of $730 \pm 70 \mathrm{~kg}$ and cannulated at the rumen with $10 \mathrm{~cm}$ diameter and $7.5 \mathrm{~cm}$ wide cannulas. The animals were kept in a roofed facility with individual compartments with cement feeders and automatic fountains.

Treatments and experimental design. The animals were assigned to one of the three isocaloric ( $1.55 \mathrm{Mcal}$ of $E L_{\mathrm{l}} / \mathrm{kg}$ of $\mathrm{DM}$ ) and isoproteic experimental diets ( $12.10 \%$ of $\mathrm{CP})$, formulated with the program Spartan Dairy Ration Evaluator/Balancer, version 3.0.3., varying according to the energetic source used, as follows: 1) Control: Low ether extract (3.50\% EE); 2) Soy: High ether extract (5.30\% EE) with an inclusion of $15 \%$ soybean, and 3 ) Citrus Pulp: Low ether extract diet $(3.00 \%$ EE) and high pectin participation with inclusion of $15 \%$ citrus pulp.

The experimental design used was a replicated $3 \times 3$ Latin square. The experimental unit was the animal within each period. The experiment included 18 experimental units: 3 animals, 3 periods and 2 squares. rumen, genera acetato como producto final, como ocurre con la fermentación de la celulosa. De esta forma, el remplazo de fuentes de almidón por pulpa cítrica puede promover efectos benéficos, principalmente con relación al ambiente ruminal, por el efecto tamponante de la pectina, resultando en mejores condiciones para la digestión de la fibra del forraje, cuando se tienen dietas ricas en concentrados (5). Por el contrario, grasas y aceites han sido añadidas en dietas para rumiantes con el objetivo de aumentar la concentración energética de la dieta. Sin embargo, unos de los problemas principales con la utilización de grasas en la dieta de rumiantes, especialmente cuando estas son insaturadas, es el efecto negativo sobre el consumo de materia seca y la reducción de la digestibilidad de la fibra (5).

De acuerdo con lo anteriormente mencionado, la evaluación nutricional de esos alimentos se torna necesaria para la caracterización de su potencial y utilización en la formulación de dietas para rumiantes. De esta forma, el objetivo del presente trabajo fue evaluar el efecto de tres fuentes energéticas sobre el consumo, la digestibilidad aparente total y la excreción de nutrientes en bovinos.

\section{MATERIAL Y MÉTODOS}

Animales e instalaciones. El experimento fue realizado en el Departamento de Nutrición y Producción Animal, de la Facultad de Medicina Veterinaria y Zootecnia de la Universidad de São Paulo, Brasil, en las instalaciones del Establo Experimental y del Laboratorio de Nutrición Animal y Bromatologia.

Fueron utilizadas seis vacas no gestantes y no lactantes, con peso vivo medio de $730 \pm 70 \mathrm{~kg}$ y portadoras de cánula ruminal con $10 \mathrm{~cm}$ de diámetro y $7.5 \mathrm{~cm}$ de grosor. Los animales fueron mantenidos en instalación cubierta, dotada de compartimientos individuales con comederos de cemento y bebederos automáticos.

Tratamientos y diseño experimental. LoS animales fueron asignados a una de las tres dietas experimentales, isocalóricas (1.55 Mcal de EL/ $/ \mathrm{kg}$ de MS) e isoprotéicas (12.10\% de PB), formuladas con el programa Spartan Dairy Ration Evaluator/ Balancer, versión 3.0.3., variando según la fuente energética utilizada, a saber: 1) control: Dieta de bajo extracto etéreo (3.50\% de EE); 2) Soya: Dieta de alto extracto etéreo ( $5.30 \%$ de EE) con inclusión de $15 \%$ de soya en grano y 3) Pulpa Cítrica: Dieta de bajo extracto etéreo (3.00\% de EE) y alta participación de pectina con inclusión de $15 \%$ de pulpa cítrica. 
Nutritional management and experimental period. The food was offered twice a day, at 08:00 and 16:00 hours, incomplete portions. In all the diets, the source of forage used was corn silo. The proportions of the different ingredients in the experimental diets and their bramatological composition are described in table 1.

Each experimental period lasted 15 days, considering the first 10 days as adaptation periods for the diets, and the last 5 days for data collection of the evaluated parameters.

The animals were weighted on the first and last day of all the periods of this experiment. The amounts of forage and concentrate offered to the animals were weighted daily, as well as the remainders of each experimental portion in order to estimate consumption per animal.

Table 1. Proportions of ingredients and estimated and calculated bromatological composition of experimental diets expressed as a percentage of dry matter (DM \%).

\begin{tabular}{|c|c|c|c|}
\hline \multirow[b]{2}{*}{ Item } & \multicolumn{3}{|c|}{ Treatments } \\
\hline & Control & Soybean & Pulp \\
\hline \multicolumn{4}{|l|}{ Ingredients (DM \%) } \\
\hline Corn silage & 50.00 & 54.40 & 48.00 \\
\hline Grinded corn & 34.70 & 27.50 & 20.70 \\
\hline Soy flour & 12.20 & - & 13.50 \\
\hline Soybean & - & 15.00 & - \\
\hline Citrus pulp & - & - & 15.00 \\
\hline Table salt & 0.50 & 0.50 & 0.50 \\
\hline Dicalcium phosphate & 0.10 & 0.10 & 0.10 \\
\hline Limestone & 0.50 & 0.50 & 0.50 \\
\hline Mineral supplement ${ }^{1}$ & 2.00 & 2.00 & 2.00 \\
\hline \multicolumn{4}{|c|}{ Bromatological composition } \\
\hline Dry matter ${ }^{2}(\%)$ & 53.10 & 51.00 & 54.00 \\
\hline $\mathrm{CP}^{2}(\% \mathrm{DM})$ & 12.10 & 12.10 & 12.10 \\
\hline $\mathrm{PDR}^{3}(\% \mathrm{CP})$ & 65.10 & 67.10 & 68.40 \\
\hline $\operatorname{PNDR}^{3}(\% \mathrm{CP})$ & 34.90 & 32.90 & 31.60 \\
\hline $\mathrm{NDF}^{2}(\% \mathrm{DM})$ & 27.10 & 31.00 & 27.90 \\
\hline $\mathrm{ADF}^{2}(\% \mathrm{DM})$ & 14.40 & 19.30 & 16.60 \\
\hline ASTARCH $^{2}(\%$ DM $)$ & 39.30 & 34.40 & 29.30 \\
\hline $\mathrm{MM}^{2}(\% \mathrm{DM})$ & 7.60 & 7.10 & 8.10 \\
\hline $\mathrm{Ca}^{2}(\% \mathrm{DM})$ & 0.85 & 0.72 & 1.01 \\
\hline $\mathrm{P}^{2}(\% \mathrm{DM})$ & 0.51 & 0.59 & 0.62 \\
\hline $\mathrm{EE}^{2}(\% \mathrm{DM})$ & 3.50 & 5.30 & 3.00 \\
\hline $\mathrm{EL}_{1}{ }^{3}$ (Mcal/kg) & 1.55 & 1.55 & 1.55 \\
\hline
\end{tabular}

${ }^{1}$ Mineral and vitamin supplement, amount per $\mathrm{kg}$ of product: $200 \mathrm{~g}$ of calcium, $60 \mathrm{~g}$ of phosphorus, $20 \mathrm{~g}$ of sulfur, $20 \mathrm{~g}$ of magnesium, $70 \mathrm{~g}$ of sodium, 15 $\mathrm{mg}$ of cobalt, $700 \mathrm{mg}$ of copper, $700 \mathrm{mg}$ of iron, $40 \mathrm{mg}$ of iodine, 1,600 $\mathrm{mg}$ of manganese, $19 \mathrm{mg}$ of selenium, $2.500 \mathrm{mg}$ of zinc, $200.000 \mathrm{IU}$ of vitamin A, 50.000 IU of vitamin D3, 1.500 IU of vitamin E. ${ }^{2}$ Estimated by bromatological analysis, determined in the Laboratory of Animal Nutrition and Food Science of the Department of Animal Nutrition and Production of the Faculty of Veterinary Medicine and Animal Husbandry of the University of São Paulo. ${ }^{3}$ Estimated through the software Spartan Dairy Ration Evaluator/ Balancer, version 3.0.3.
El diseño experimental utilizado fue un cuadrado latino $3 \times 3$ replicado. La unidad experimental fue el animal dentro de cada período. El experimento contó con 18 unidades experimentales referentes a 3 animales, 3 períodos y 2 cuadrados.

Manejo nutricional y período experimental. Los alimentos fueron ofrecidos dos veces al día, a las 08:00 y 16:00 horas, en forma de ración completa. En todas las dietas, la fuente de forraje utilizado fue el ensilaje de maíz. Las proporciones de los diversos ingredientes de las dietas experimentales y la composición bromatológica de las mismas están descritas en la tabla 1.

Cada período experimental fue constituido de 15 días, considerando los primeros 10 días para adaptación a las dietas y los últimos 5 días para colecta de datos de los parámetros evaluados.

En todos los períodos del presente experimento, los animales fueron pesados en el primero y último día. Diariamente se pesaron las cantidades de forraje y concentrados ofrecidos así como de las sobras de cada ración experimental para estimar el consumo por animal.

Parámetros de evaluación. El consumo de materia seca (CMS) fue evaluado diariamente, entre el día 10 hasta el día 15 de cada período experimental. El CMS fue calculado por la cantidad de alimento suministrado en un día y sustraído por la respectiva sobra de alimento colectado y pesado en la mañana siguiente al ofrecimiento de las dietas, multiplicando esto por el porcentaje de materia seca (MS) del alimento.

Las muestras de los alimentos utilizados en las dietas fueron analizadas para determinar el porcentaje de materia seca - MS (Método 2001.12), materia mineral - MM (Método 935.12), proteína bruta PB (Método 968.06), extracto etéreo - EE (Método 920.39), calcio - Ca (Método 935.13), fósforo - $P$ (Método 964.06), conforme metodologías descritas por AOAC (6); energía bruta - EB, determinada mediante bomba calorimétrica adiabática PARR Instruments ${ }^{\circledR}$ y fibra en detergente neutro - FDN, fibra en detergente ácido - FDA y lignina - LIG, según Van Soest (3).

La digestibilidad aparente total de la MS de la dieta y sus fracciones (PB, EE, EB, ENN, FDN, FDA y $\mathrm{MO}$ ) fueron determinadas por medio del marcador de óxido de cromo $\left(\mathrm{Cr}_{2} \mathrm{O}_{3}\right)$, según la técnica mencionada por Bateman (7). Para tal, entre el día 5 hasta el día 15 de suministro de las dietas de cada periodo experimental, fueron administrados dos veces al día, vía cánula ruminal, $2 \mathrm{~g}$ del marcador de $\mathrm{Cr}_{2} \mathrm{O}_{3}$ por $\mathrm{kg}$ de MS de alimento 
Evaluation parameters. Dry matter consumption (DMC) was evaluated daily, between days 10 and 15 of each experimental period. DMC was calculated as the amount of food provided in one days and withdrawn from its corresponding leftover, and weighted the next morning, upon offering the diets, multiplying this by the percentage of dry matter (DM) in food.

Samples of the food used in the diets were analyzed to determine the percentage of dry matter - DM (Method 2001.12), mineral matter - MM (Method 935.12), gross protein - GP (Method 968.06), ether extract - EE (Method 920.39), calcium - Ca (Method 935.13), Phosphorous - P (Method 964.06), according to methodologies described by AOAC (6); gross energy - GE, determined by adiabatic calorimeter PARR Instruments ${ }^{\circledR}$ and fiber in neutral detergent - FND, acid detergent fiber ADF and lignin - LIG, according to Van Soest (3).

Total apparent digestibility of DM in the diet and its fractions (GP, EE, GE, ENN, FND, ADF y $\mathrm{OM}$ ) were determined with a chromium oxide marker $\left(\mathrm{Cr}_{2} \mathrm{O}_{3}\right)$, according to the technique mentioned by Bateman (7). For this, $2 \mathrm{~g}$ of the marker $\mathrm{Cr}_{2} \mathrm{O}_{3}$ per $\mathrm{kg}$ of DM consumed were administered through the ruminal cannula. For such, between day 5 to day 15 of the supply of the diets of each experimental period, $2 \mathrm{~g}$ of the marker $\mathrm{Cr}_{2} \mathrm{O}_{3}$ per $\mathrm{kg}$ of DM of consumed food were administered two times a day via the rumen cannula through wrappers made from absorbent paper. The digestibility assay was established in two phases, the first five days for adaptation to the marker and the last five for stool collection.

For the analysis of the composition of fecal samples, an aliquot of $200 \mathrm{~g}$ per animal was directly removed from the rectum twice a day, which was preserved in the plastic wrap previously identified for each animal and experimental period. During that same period, approximately $200 \mathrm{~g}$ of each food offered in the total ration and stored in the plastic wraps previously identified were collected twice a day. All samples were kept at $-20^{\circ} \mathrm{C}$ until analysis. Food and feces samples were homogenized and pre-dried in a forced ventilation stove at $65^{\circ} \mathrm{C}$ for 72 hours. They were subsequently crushed in a mill using a $1.0 \mathrm{~mm}$ sieve and coupled into closed bottles for the determination of the $\mathrm{Cr}_{2} \mathrm{O}_{3}$ concentration, according to the methodology described by Conceição et al. (8), and other lab tests. consumido, a través de envolturas confeccionadas en papel absorbente. El ensayo de digestibilidad fue constituido de dos fases, siendo los cinco primeros días para adaptación al marcador y los cinco últimos para colecta de heces.

Para análisis de la composición de las muestras de heces, se retiró una alícuota de $200 \mathrm{~g}$ por animal directamente del recto, dos veces al día, la cual fue conservada en envoltura plástica previamente identificada para cada animal y período experimental. Durante ese mismo período, fueron colectados, dos veces al día, aproximadamente $200 \mathrm{~g}$ de cada alimento ofrecido en la ración total y almacenados en envolturas plásticas previamente identificadas. Todas las muestras fueron mantenidas a $-20^{\circ} \mathrm{C}$ hasta el momento de análisis. Las muestras de los alimentos y de las heces fueron homogenizadas y sometidas a presecado en estufa de ventilación forzada a $65^{\circ} \mathrm{C}$ por 72 horas. Posteriormente fueron trituradas en molino, utilizándose un tamiz de $1.0 \mathrm{~mm}$ y acopladas en frascos cerrados para determinación de la concentración de $\mathrm{Cr}_{2} \mathrm{O}_{3}$, conforme metodología descrita por Conceição et al (8), y demás análisis de laboratorio.

La concentración de nutrientes digestibles totales (NDT) de las dietas, fue calculada a través de la ecuación propuesta por el NRC (9):

$\mathrm{NDT}(\%)=\mathrm{PBD}+\mathrm{FDND}+\mathrm{CNFD}+(2.25 \times \mathrm{EED})-7$

Dónde:

PBD = proteína bruta digestible;

FDND = fibra en detergente neutro digestible;

CNFD = carbohidratos no fibrosos digestibles;

$\mathrm{EED}=$ extracto etéreo digestible.

La excreción de MS y de los nutrientes de la dieta, fueron calculadas a partir de los datos del coeficiente de digestibilidad de la MS y sus fracciones, multiplicando el valor del consumo de los nutrientes por sus respectivos coeficientes de digestibilidad y dividiendo esto por 100 .

Análisis estadístico. Los resultados fueron analizados por el programa Statistical Analysis System, Versión 9.2 (10), verificando anteriormente la normalidad de los residuos por el test de ShapiroWilk. Los datos fueron sometidos a análisis de varianza por el procedimiento MIXED del SAS, donde el modelo incluyó el efecto de tratamiento como factor fijo y los efectos de animal dentro del cuadrado, cuadrado y periodo como factores aleatorios. Los efectos de tratamiento fueron evaluados por el test de Tukey $(p<0.05)$. 
The concentration of total digestible nutrients (TDN) of diets was calculated through the equation proposed by NRC (9):

$\operatorname{TDN}(\%)=\mathrm{DCP}+\mathrm{DNDF}+\mathrm{DNFC}+(2.25 \times \mathrm{DEE})-7$

Where:

DCP = digestible crude protein;

DNDF = digestible neutral detergent fiber;

DNFC = digestible not fibrous carbohydrates;

DEE $=$ digestible ether extract.

The excretion of DM and the nutrients of the diet were calculated from the data of the DM digestibility coefficient and its fractions, multiplying the nutrient intake value by their respective digestibility coefficients and dividing it by 100 .

Statistical analysis. The results were analyzed by the software Statistical Analysis System, Version 9.2 (10), before checking the normality of waste by the Shapiro-Wilk test. The data were subjected to analysis of variance by the SAS MIXED procedure, where the model included the effect of the treatment as a fixed factor and the effects of animal within the square, square and period as random factors. The effects of the treatment were evaluated by the Tukey test $(p<0.05)$.

The mathematical model used was:

$y_{i j k}=m+a_{i}+t_{j}+b_{k}+e_{i j k}$

Where:

$\mathrm{y}_{\mathrm{ijk}}$ is the observation in line $I$ and column $k$ of treatment $j$;

$\mathrm{m}$ is the general average;

$a_{i}$ is the effect of column $I$ in the square;

$t_{j}$ is the effect of treatment $j$;

$b_{k}$ is the effect of line $k$.

$\mathrm{e}_{\mathrm{ijk}}$ is the random experimental error.

Ethical considerations. This experiment was conducted according to the guidelines established by the ethics committee on the use of animals of the Faculty of Veterinary Medicine and Animal Husbandry of the University of São Paulo (Brazil), under Protocol No. 2262/2011, in accordance with the ethical principles for animal experimentation, animal care and use.

\section{RESULTS}

Table 2 shows the mean values of the consumption of dry matter and nutrients for the effects of the energy source.
El modelo matemático utilizado fue:

$y_{i j k}=m+a_{i}+t_{j}+b_{k}+e_{i j k}$

Donde:

$y_{i j k}$ es la observación en la i-ésima línea y k-ésima columna del j-ésimo tratamiento;

$\mathrm{m}$ es el promedio general;

$a_{i}$ es el efecto de la i-ésima columna dentro de cuadrado;

$t_{j}$ es el efecto del $j$-ésimo tratamiento;

$b_{k}$ es el efecto de la $k$-ésima línea.

$\mathrm{e}_{\mathrm{ijk}}$ es el error experimental aleatorio

Consideraciones éticas. Este experimento fue conducido de acuerdo con las directrices establecidas por la comisión de ética del uso de animales de la Facultad de Medicina Veterinaria y Zootecnia de la Universidad de São Paulo (Brasil), bajo el protocolo Nro. 2262/2011, estando de acuerdo con los principios éticos de experimentación animal, para el cuidado y uso de los animales.

\section{RESULTADOS}

En la tabla 2 se presentan los valores medios del consumo de materia seca y de los nutrientes, para los efectos de fuente energética.

No hubo efecto de fuente energética sobre el consumo de energía bruta (CEB), ni de fibra en detergente neutro (CFDN), probablemente, porque los animales recibieron dietas isocalóricas con valores semejantes de FDN (Tabla 1), lo que proporcionó a lo largo del día un consumo constante de estos nutrientes, indicando que las condiciones ruminales se mantuvieron también constantes para los tratamientos.

Table 2. Effect of three energy sources on the consumption of DM and nutrients.

\begin{tabular}{|c|c|c|c|c|c|}
\hline \multirow[b]{2}{*}{ Variables } & \multicolumn{3}{|c|}{ Treatments } & \multirow[b]{2}{*}{ SD } & \multirow[b]{2}{*}{ p-value } \\
\hline & Control & Soybean & Citric Pulp & & \\
\hline CMS (kg/day) & $\begin{array}{c}16.42 \\
\pm 0.95^{\mathrm{a}}\end{array}$ & $\begin{array}{c}14.68 \\
\pm 1.50^{\mathrm{b}}\end{array}$ & $\begin{array}{l}16.37 \\
\pm 0.82^{\mathrm{a}}\end{array}$ & 0.32 & 0.0196 \\
\hline CPB (kg/day) & $\begin{array}{c}1.87 \\
\pm 0.07^{\mathrm{a}}\end{array}$ & $\begin{array}{c}1.67 \\
\pm 0.19^{\mathrm{b}}\end{array}$ & $\begin{array}{c}1.99 \\
\pm 0.11^{\mathrm{a}}\end{array}$ & 0.04 & 0.0048 \\
\hline CEB (Mcal/day) & $\begin{array}{l}70.23 \\
\pm 4.15\end{array}$ & $\begin{array}{l}69.25 \\
\pm 6.59\end{array}$ & $\begin{array}{l}64.39 \\
\pm 3.44\end{array}$ & 1.25 & 0.0775 \\
\hline CFDN (kg/day) & $\begin{array}{c}4.43 \\
\pm 0.23\end{array}$ & $\begin{array}{c}4.53 \\
\pm 0.49\end{array}$ & $\begin{array}{c}4.52 \\
\pm 0.26\end{array}$ & 0.08 & 0.7848 \\
\hline CFDA (kg/day) & $\begin{array}{c}2.34 \\
\pm 0.21^{\mathrm{b}}\end{array}$ & $\begin{array}{c}2.83 \\
\pm 0.38^{\mathrm{a}}\end{array}$ & $\begin{array}{c}2.68 \\
\pm 0.15^{\mathrm{a}}\end{array}$ & 0.08 & 0.0073 \\
\hline CEE (kg/day) & $\begin{array}{c}0.57 \\
\pm 0.04^{b}\end{array}$ & $\begin{array}{c}0.78 \\
\pm 0.08^{\mathrm{a}}\end{array}$ & $\begin{array}{c}0.49 \\
\pm 0.04^{b}\end{array}$ & 0.03 & $<0.0001$ \\
\hline CENN (kg/day) & $\begin{array}{c}8.30 \\
\pm 0.57^{a}\end{array}$ & $\begin{array}{c}6.64 \\
\pm 0.64^{\mathrm{b}}\end{array}$ & $\begin{array}{c}8.01 \\
\pm 0.37^{a}\end{array}$ & 0.21 & 0.0005 \\
\hline CMO (kg/day) & $\begin{array}{c}15.17 \\
\pm 0.91^{\mathrm{a}}\end{array}$ & $\begin{array}{c}13.63^{ \pm} \\
1.38^{\mathrm{b}}\end{array}$ & $\begin{array}{c}15.02 \\
\pm 0.75^{\mathrm{ab}}\end{array}$ & 0.29 & 0.0273 \\
\hline
\end{tabular}

$\overline{{ }^{a b} \text { Different letters in the same line indicate significant differences }(p<0.05)}$ through the Tukey test. 
There was no effect of the energy source over the gross energy consumption (GEC) or neutral detergent fiber (NDFC), probably because the animals received isocaloric diets with similar values of NDF (Table 1), which provided a constant intake of these nutrients throughout the day, indicating that the ruminal conditions also remained constants for treatments.

A decrease in the consumption of dry matter (DMC), crude protein (CPC) and nitrogen- free extract (NFEC) was observed $(p<0.05)$ for the soybean treatment as compared to the control and citrus pulp treatments, which in turn were not different from each other. The soybean treatment also reduced $(p<0.05)$ the consumption of organic matter (OMC) when compared with the control treatment and there were no significant differences between these two treatments with regard to the citrus pulp treatment. The depressant effect of lipids on dry matter intake was due to satiety, the decrease in dry matter intake resulted in the decrease of the consumption of crude protein, nitrogen-free extract and organic matter.

The acid detergent fiber consumption (ADFC) was lower $(p<0.05)$ for animals receiving the control treatment than in those that consumed soybean grains or citrus pulp, there being no statistical difference between these last two treatments. This is due to the fact that in the bromatological composition (Table 1), the value for ADF in the control treatment was lower when compared to the ADF content in soybean or citrus pulp treatments. In addition, the increase in the consumption of ADF for soybean or citrus pulp diets was due to the higher content of fibers in these diets, as these sources have a higher ADF percentage when compared with corn.

The effect of the energy source $(p<0.05)$ was observed for the consumption of ether extract (EEC), being this higher for the soybean treatment in relation to the other treatments that, at the same time, were not different among them. This was to be expected since the treatment containing soybean grains was characterized for being a high ether extract diet ( $5.30 \%$ of EE), which means that a portion of non-fibrous carbohydrates was replaced by ether extract.

The results of the DM digestibility coefficients and its fractions, as well as total digestible nutrients, are described in Table 3.

The digestibility coefficients for DM, CP, GE, NDF, $E E, N F E$ and OM were not affected by any of the treatments. There was a significant effect for the digestibility coefficient of ADF as well as for TDN.
Se observó la disminución $(\mathrm{p}<0.05)$ en el consumo de materia seca (CMS), de proteína bruta (CPB) y de extracto no nitrogenado (CENN) para el tratamiento con soya en comparación a los tratamientos control y pulpa cítrica, que a la vez, estos últimos no fueron diferentes entre sí. El tratamiento con soya disminuyó $(p<0.05)$ también el consumo de materia orgánica (CMO) cuando fue comparado con el tratamiento control y no presentando diferencias significativas estos dos tratamientos respecto al tratamiento con pulpa cítrica. El efecto depresor de los lípidos sobre el consumo de materia seca fue debido a un efecto de saciedad, cuya disminución de la ingestión de materia seca resultó en disminución del consumo de proteína bruta, de extracto no nitrogenado y de materia orgánica.

El consumo de fibra en detergente ácido (CFDA) fue menor $(p<0.05)$ para los animales que recibieron el tratamiento control que para los que consumieron granos de soya o pulpa cítrica, no presentando diferencias estadísticas estos dos últimos tratamientos. Esto es debido, a que en la composición bromatológica (Tabla 1) el valor de FDA del tratamiento control fue menor con relación al contenido de FDA de los tratamientos con soya o pulpa cítrica. Además, el aumento del consumo de FDA para las dietas con soya o pulpa cítrica, fue debido al mayor contenido de fibras en esas dietas, toda vez que estas fuentes poseen un mayor porcentaje de FDA, cuando comparados con el maíz.

Efecto de fuente energética $(p<0.05)$ fue observado para el consumo de extracto etéreo (CEE), siendo este mayor para el tratamiento con soya con relación a los demás tratamientos que, a la vez, no fueron diferentes entre sí. Esto es esperado, debido a que el tratamiento que contenía granos de soya se caracterizó por ser una dieta con alto extracto etéreo $(5.30 \%$ de $\mathrm{EE})$, lo que significa que parte de los carbohidratos no fibrosos fueron sustituidos por extracto etéreo.

Los resultados de los coeficientes de digestibilidad de la MS y sus fracciones, así como los nutrientes digestibles totales se describen en la tabla 3.

Los coeficientes de digestibilidad de la MS, PB, EB, FDN, EE, ENN y MO no fueron afectados por ninguno de los tratamientos. Hubo efecto significativo para el coeficiente de digestibilidad de FDA, así como para los NDT.

Las fuentes energéticas utilizadas en el presente experimento influyeron en los valores de excreción de la MS y de los nutrientes, como se observa en la tabla 4. Entre tanto, no fueron encontrados datos en la literatura acerca del efecto de fuentes energéticas sobre la excreción de nutrientes de la dieta de bovinos. 
Table 3. Effect of three energy sources on the apparent total digestibility of DM and its fractions.

\begin{tabular}{|c|c|c|c|c|c|}
\hline \multirow{2}{*}{ Variables } & \multicolumn{3}{|c|}{ Treatments } & \multirow{2}{*}{ SD } & \multirow{2}{*}{ p-value } \\
\hline & Control & Soybean & Citric Pulp & & \\
\hline CDMS (\%) & $\begin{array}{l}88.87 \\
\pm 0.48\end{array}$ & $\begin{array}{l}88.57 \\
\pm 1.40\end{array}$ & $\begin{array}{l}89.41 \\
\pm 0.95\end{array}$ & 0.61 & 0.2516 \\
\hline CDPB (\%) & $\begin{array}{l}87.58 \\
\pm 0.76\end{array}$ & $\begin{array}{l}86.58 \\
\pm 1.70\end{array}$ & $\begin{array}{l}87.37 \\
\pm 0.62\end{array}$ & 0.72 & 0.1630 \\
\hline CDEB (\%) & $\begin{array}{l}89.11 \\
\pm 0.64\end{array}$ & $\begin{array}{l}88.50 \\
\pm 1.31\end{array}$ & $\begin{array}{l}89.76 \\
\pm 0.87\end{array}$ & 0.56 & 0.0623 \\
\hline CDFDN (\%) & $\begin{array}{l}85.89 \\
\pm 0.97\end{array}$ & $\begin{array}{l}85.79 \\
\pm 1.33\end{array}$ & $\begin{array}{l}85.94 \\
\pm 1.28\end{array}$ & 0.58 & 0.9733 \\
\hline CDFDA (\%) & $\begin{array}{l}81.96 \\
\pm 1.99^{\mathrm{b}}\end{array}$ & $\begin{array}{c}83.36 \\
\pm 1.87^{\mathrm{ab}}\end{array}$ & $\begin{array}{l}85.21 \\
\pm 1.60^{\mathrm{a}}\end{array}$ & 0.78 & 0.0409 \\
\hline CDEE (\%) & $\begin{array}{l}92.21 \\
\pm 2.47\end{array}$ & $\begin{array}{l}94.04 \\
\pm 2.32\end{array}$ & $\begin{array}{l}95.21 \\
\pm 1.48\end{array}$ & 0.95 & 0.0980 \\
\hline CDENN (\%) & $\begin{array}{l}92.20 \\
\pm 0.91\end{array}$ & $\begin{array}{l}92.52 \\
\pm 1.18\end{array}$ & $\begin{array}{l}93.28 \\
\pm 1.15\end{array}$ & 0.47 & 0.1278 \\
\hline CDMO (\%) & $\begin{array}{l}89.78 \\
\pm 0.59\end{array}$ & $\begin{array}{l}89.64 \\
\pm 1.13\end{array}$ & $\begin{array}{l}90.35 \\
\pm 0.96\end{array}$ & 0.49 & 0.2206 \\
\hline TDN (\%) & $\begin{array}{l}86.98 \\
\pm 0.69^{b}\end{array}$ & $\begin{array}{l}89.50 \\
\pm 1.21^{\mathrm{a}}\end{array}$ & $\begin{array}{l}86.61 \\
\pm 0.88^{b}\end{array}$ & 0.50 & 0.0003 \\
\hline
\end{tabular}

The energy sources used in this experiment influenced the excretion values for DM and nutrients as shown in table 4. Moreover, no data were found in the literature about the effect of energy sources on the excretion of nutrients from cattle diet.

Significant differences ( $p>0.05)$ were not observed between treatments for the excretion of gross energy (GEEX), and neutral detergent fiber (NDFEx). The excretion of dry matter (DMEX), nitrogen-free extract (NFEEx) and organic matter (OMEx) were lower $(p<0.05)$ for the soybean treatment in comparison to the control treatment, without differences of these two with the citrus pulp treatment. This is related to the consumption (Table 2 ) obtained for these nutrients, being also lower when animals consumed the soybean treatment.

The excretion of acid detergent fiber (ADFEx) and ether extract (EEEx) was higher $(p<0.05)$ for the soybean treatment in relation to the citrus pulp treatment, with these two treatments not being different from the control treatment.

The energy source effect was observed $(p<0.05)$ for the excretion of crude protein (CPEx), being all treatments different among each other, while the citrus pulp treatment promoted an increased protein excretion, while the soybean treatment resulted in a lower excretion of this nutrient. The same effect $(p<0.05)$ was observed for the excretion of nitrogen (NEx), being higher for the citrus pulp treatment as compared to the soybean treatment. Based on these findings it can be asserted that the increased excretion of protein crude, and consequently of nitrogen, for the citrus pulp treatment is due to a lower
Table 4. Effect of three energy sources on the excretion of DM and nutrients.

\begin{tabular}{|c|c|c|c|c|c|}
\hline \multirow{2}{*}{ Variables } & \multicolumn{3}{|c|}{ Treatments } & \multirow{2}{*}{ SD } & \multirow{2}{*}{ p-value } \\
\hline & Control & Soybean & Citric Pulp & & \\
\hline DMEx (kg/day) & $\begin{array}{c}1.82 \\
\pm 0.12^{\mathrm{a}}\end{array}$ & $\begin{array}{c}1.67 \\
\pm 0.13^{\mathrm{b}}\end{array}$ & $\begin{array}{c}1.73 \\
\pm 0.11^{\mathrm{ab}}\end{array}$ & 0.030 & 0.0567 \\
\hline CPEx (kg/day) & $\begin{array}{c}0.23 \\
\pm 0.01^{\mathrm{b}}\end{array}$ & $\begin{array}{c}0.22 \\
\pm 0.02^{\mathrm{c}}\end{array}$ & $\begin{array}{c}0.25 \\
\pm 0.01^{\mathrm{a}}\end{array}$ & 0.005 & 0.0020 \\
\hline GEEx (Mcal/day) & $\begin{array}{l}7.64 \\
\pm 4.56\end{array}$ & $\begin{array}{r}7.35 \\
\pm 5.27\end{array}$ & $\begin{array}{l}7.08 \\
\pm 4.83\end{array}$ & 0.122 & 0.0898 \\
\hline NDFEx (kg/day) & $\begin{array}{l}0.62 \\
\pm 0.04\end{array}$ & $\begin{array}{l}0.64 \\
\pm 0.06\end{array}$ & $\begin{array}{l}0.63 \\
\pm 0.04\end{array}$ & 0.010 & 0.8262 \\
\hline ADFEx (kg/day) & $\begin{array}{c}0.42 \\
\pm 0.03^{\mathrm{ab}}\end{array}$ & $\begin{array}{c}0.47 \\
\pm 0.04^{\mathrm{a}}\end{array}$ & $\begin{array}{c}0.40 \\
\pm 0.04^{b}\end{array}$ & 0.011 & 0.0293 \\
\hline ExEE (kg/day) & $\begin{array}{c}0.043 \\
\pm 0.01^{\mathrm{ab}}\end{array}$ & $\begin{array}{c}0.045 \\
\pm 0.01^{\text {a }}\end{array}$ & $\begin{array}{c}0.023 \\
\pm 0.05^{b}\end{array}$ & 0.004 & 0.0266 \\
\hline NFEEx (kg/day) & $\begin{array}{c}0.65 \\
\pm 0.09^{\mathrm{a}}\end{array}$ & $\begin{array}{c}0.49 \\
\pm 0.05^{\mathrm{b}}\end{array}$ & $\begin{array}{c}0.54 \\
\pm 0.08^{\mathrm{ab}}\end{array}$ & 0.023 & 0.0048 \\
\hline OMEx (kg/day) & $\begin{array}{c}1.55 \\
\pm 0.11^{\mathrm{a}}\end{array}$ & $\begin{array}{c}1.40 \\
\pm 0.09^{\mathrm{b}}\end{array}$ & $\begin{array}{c}1.45 \\
\pm 0.11^{\mathrm{ab}}\end{array}$ & 0.028 & 0.0308 \\
\hline NEx (kg/day) & $\begin{array}{c}0.038 \\
\pm 0.004 \mathrm{ab}\end{array}$ & $\begin{array}{c}0.035 \\
\pm 0.005^{\mathrm{b}}\end{array}$ & $\begin{array}{c}0.042 \\
\pm 0.004^{\mathrm{a}}\end{array}$ & 0.001 & 0.0084 \\
\hline
\end{tabular}

No fueron observadas diferencias significativas $(p>0.05)$ entre los tratamientos para la excreción de energía bruta (ExEB), y de fibra en detergente neutro (ExFDN). La excreción de materia seca (EXMS), de extracto no nitrogenado (EXENN) y de materia orgánica (ExMO) fueron menores $(p<0.05)$ para el tratamiento con soya en comparación al tratamiento control, sin diferencias de estos dos con el tratamiento con pulpa cítrica. Esto está relacionado con el consumo (Tabla 2) obtenido para estos nutrientes, siendo que también fue menor cuando los animales consumieron el tratamiento con soya.

La excreción de fibra en detergente ácido (ExFDA) y de extracto etéreo (ExEE) fue más elevada $(p<0.05)$ para el tratamiento con granos de soya en relación al tratamiento con pulpa cítrica, no diferenciándose estos dos tratamientos del tratamiento control.

Efecto de fuente energética fue observado $(p<0.05)$ para la excreción de proteína bruta (ExPB), diferenciándose todos los tratamientos entre sí, siendo que el tratamiento con pulpa cítrica promovió una mayor excreción de proteína, mientras que el tratamiento con soya resultó en menor excreción de este nutriente. El mismo efecto $(p<0.05)$, fue observado para la excreción de nitrógeno (ExN), siendo más elevada para el tratamiento con pulpa cítrica en comparación al tratamiento con soya. De acuerdo con estos resultados, se puede decir que la mayor excreción de proteína bruta, y consecuentemente de nitrógeno, para el tratamiento con pulpa cítrica es debido a una menor retención de los compuestos nitrogenados por parte de los animales que recibieron este tratamiento. 
retention of the nitrogenous compounds by the animals that received this treatment.

\section{DISCUSSION}

The depressant effect of lipids on DMC and the nutrients mentioned above is associated with the inhibition of the microbial activity and consequently, with the rate of digestion. The use of lipids in the diet of bovine cattle may affect fiber digestibility, mainly when these are unsaturated fatty acids (11). This inhibitory effect on fiber degradation has been attributed to a coat of fibrous particles with fat, which generates a physical impediment that lipids exert on microorganisms through a hydrophobic layer, preventing the metabolism and perfect adherence of bacteria to the fiber, thus affecting the proximity of fibrolytic enzymes to the fibrous material (12). On the other hand, the reduction in DMC with the inclusion of lipids is associated with a reduction of ruminal motility and rumination time, which results in a slower transit of digestion and a satiety effect by physical filling based on lower fiber degradation (13). In the case of soybeans, the natural fibrous coverage of the seed shell that surrounds the whole oily grains, can potentially alter the ruminal passage rate or the release of oil within the rumen (14). The NRC (9) indicates a reduction in DMC in animals receiving soybeans, according to the reduction in the fiber digestibility and at the same time the increase in time of permanence of food in the reticulum-rumen.

The decrease of the CMS is also given by the interference of unsaturated lipids on the activity Gram - negative bacteria, mainly responsible for fiber fermentation (15). The excess of unsaturated fatty acids can cause alteration in ruminal fermentation due to the suppression of the activity of cellulolytic and methanogenic bacteria. This is due to a physicochemical effect generated by the interaction between free fatty acids and bacteria, through a toxic effect of unsaturated fatty acids on microorganisms, where an alteration in the cytoplasmic membrane occurs affecting its permeability (12). On the other hand, the high energy density of the diet might have led to an increase in the blood concentration of native metabolites from the diet (triglycerides and accordingly free fatty acids), which stimulated chemical receptors that activated the satiety center resulting in a decrease in food intake (16).

Similar results to the CMS and the nutrients found in this experiment were reported by Oliveira et al (17), when assessing the effects of

\section{DISCUSIÓN}

El efecto depresor de los lípidos sobre el CMS y de los nutrientes mencionados anteriormente, está relacionado con la inhibición de la actividad microbiana y consecuentemente, con la tasa de pasaje de la digesta. La utilización de lípidos en la dieta de bovinos puede afectar la digestibilidad de la fibra, principalmente cuando estos son ácidos grasos insaturados (11). Este efecto inhibidor sobre la degradación de la fibra se ha atribuido a un revestimiento de partículas fibrosas con la grasa, lo que genera un impedimento físico que los lípidos ejercen sobre los microorganismos por medio de una capa hidrofóbica, que impide el metabolismo y la perfecta adherencia de las bacterias a la fibra, afectando de esta forma la proximidad de las enzimas fibrolíticas al material fibroso (12). Por otro lado, la reducción del CMS con la inclusión de lípidos, está asociada a una reducción de la motilidad ruminal y del tiempo de rumia, lo que resulta en menor velocidad del tránsito de la digesta y en un efecto de saciedad por llenado físico en función de una menor degradación de la fibra (13). En el caso de la soya en grano, la cobertura fibrosa natural de la cáscara de la semilla que envuelve los granos oleaginosos enteros, puede alterar potencialmente la tasa de pasaje ruminal o la liberación de aceite para dentro del rumen (14). El NRC (9) indica una reducción del CMS en animales que reciben soya en grano, en función de la reducción de la digestibilidad de la fibra y a la vez, por el aumento del tiempo de permanencia de los alimentos en el retículo-rumen.

La disminución del CMS está dada también, por la interferencia de los lípidos insaturados sobre la actividad de las bacterias Gram- negativas, principales responsables por la fermentación de la fibra (15). El exceso de ácidos grasos insaturados puede causar alteración en la fermentación ruminal, debido a la supresión de la actividad de bacterias celuloliticas y metanogênicas. Esto es debido, a un efecto fisicoquímico generado por la interacción entre ácidos grasos libres y bacterias, a través de un efecto tóxico de los ácidos grasos insaturados sobre los microorganismos, donde ocurre una alteración en la membrana citoplasmática, afectando la permeabilidad de esta (12). Por otro lado, la alta densidad energética de la dieta pudo haber llevado a un aumento de la concentración sanguínea de metabolitos oriundos de la dieta (Triglicéridos y consecuentemente ácidos grasos libres), lo que estimuló receptores químicos que activaron el centro de saciedad ocasionando, una disminución de la ingestión de alimentos (16).

Resultados similares al CMS y de los nutrientes encontrados en el presente experimento fueron relatados por Oliveira et al (17), al evaluar los efectos de diferentes fuentes de lípidos 
different lipid sources on the consumption and digestibility of buffalo steers in confinement. The authors observed that the consumption of EE by animals fed with diets containing whole soybean grains or soybean oil was higher than those that received the treatment with no additional lipids. This greater intake of lipids resulted in lower consumption of DM, CP and CNF in animals receiving diets with whole soybean grains and soybean oil. This result can be explained by the satiety effect that was produced with the contribution of lipids in ruminant diet, explained by the theory of regulation of energy consumption described by Van Soest (3).

On the other hand, Bassi et al (12), working with 30 zebu heifers, evaluated the use of diets formulated with corn silage and four concentrates, one with no lipid supplementation and three including different oilseeds (soybean, cotton shell and flax seed) in concentrated isoproteic diets (13.3\% of CP in DM). The authors observed that the inclusion of soybeans reduced the daily intake of DM when compared to the diet without lipids ( 8.18 and $8.70 \mathrm{~kg}$, respectively). The same effect was observed for the consumption of OM (6.93 and $7.17 \mathrm{~kg}$ ); however, for the consumption of CP and NDF, no differences were observed between diets. The consumption of EE increased ( 0.51 to $0.31 \mathrm{~kg} /$ day) with the inclusion of soybean in relation to the treatment without lipids, respectively. This reduction in the CMS, according to the same authors, can be attributed to the higher energy density of diets containing oilseed grains.

In the digestibility analysis it was not possible to demonstrate effect of the energy source on the digestibility coefficients of DM, CP, GE, NDF, EE, NFE and OM. Leite (18), when working with Holstein lactating cows with a live weight of 652 $\mathrm{kg}$, indicates that there is a reduction in fiber digestibility when lipid sources such as soybean oil are added at a rate of $2 \%$ in the DM of the total diet. However, the extent of the reduction is related not only to the amount but also with the type of fatty acid present in the supplement, as rich lipids in unsaturated fatty acids tend to cause a greater reduction in digestibility. In contrast, Harvatine and Allen (19) did not observed the effects of the inclusion of up to $8.3 \%$ of saturated and unsaturated fatty acids on the digestibility of DM, OM, NDF and starch in multiparous Holstein cattle; hence suggesting that large quantities ( $8.3 \%$ ) of fatty acids may be added to diets as this does not produce any effect on digestibility. sobre el consumo y la digestibilidad de novillos búfalos terminados en confinamiento. Los autores observaron que el consumo de EE por los animales alimentados con dietas que contenían grano de soya integral o aceite de soya fue mayor al de aquellos que recibieron el tratamiento sin lípido adicional. Esa mayor ingestión de lípidos provocó menores consumos de MS, PB e CNF en los animales que recibieron las dietas con grano de soya integral y aceite de soya. Ese resultado puede ser explicado por el efecto de saciedad que ocurrió con el aporte de los lípidos en la alimentación de los rumiantes, explicado por la teoría de la regulación del consumo por la energía, descrito por Van Soest (3).

Por otro lado, Bassi et al (12), trabajando con 30 novillos cebuínos, evaluaron el uso de dietas formuladas con ensilaje de maíz y cuatro concentrados, siendo uno sin suplementación de lípidos y tres con inclusión de diferentes granos de oleaginosas (grano de soya, cáscara de algodón y semilla de linaza) en dietas concentradas isoprotéicas ( $13.3 \%$ de PB en MS). Los autores observaron que la inclusión de soya redujo el consumo diario de MS en comparación a la dieta sin inclusión de lípido ( 8.18 y 8.70 kg, respectivamente). El mismo efecto fue observado para el consumo de MO (6.93 y $7.17 \mathrm{~kg})$; sin embargo, para el consumo de PB y de FDN, no fueron observadas diferencias entre las dietas. El consumo de EE aumentó ( 0.51 a $0.31 \mathrm{~kg} /$ día) con la inclusión de soya con relación al tratamiento sin adición de lípido, respectivamente. Esta reducción en el CMS, de acuerdo con los mismos autores, puede ser atribuida a la mayor densidad energética de las dietas que contenían granos de oleaginosas.

En el análisis de digestibilidad, no fue posible demonstrar efecto de fuente energética sobre los coeficientes de digestibilidad de la MS, PB, EB, FDN, EE, ENN y MO. Leite (18) al trabajar con vacas holandesas en lactacia, con un peso vivo de $652 \mathrm{~kg}$, señala que existe una reducción en la digestibilidad de la fibra cuando fuentes lipídicas como el aceite de soya son adicionadas en una proporción de $2 \%$ en la MS de la dieta total. Sin embargo, la magnitud de reducción está relacionada no sólo con la cantidad, sino también con el tipo de ácido graso presente en el suplemento, una vez que lípidos ricos en ácidos grasos insaturados tienden a provocar una mayor reducción en la digestibilidad. En contraste, Harvatine y Allen (19) no observaron efectos de la inclusión de hasta $8.3 \%$ de ácidos grasos saturados e insaturados, sobre la digestibilidad de la MS, MO, FDN y almidón, en vacas multíparas de raza holandesa; sugiriendo de esta forma, que grandes cantidades $(8.3 \%)$ de ácidos grasos pueden ser adicionados a las dietas al no presentar efectos en la digestibilidad. 
The citrus pulp treatment showed a greater $(p<0.05)$ digestibility of the ADF fraction when compared with the control treatment. This is explained because the fibrous fraction of citrus pulp has a high ruminal digestibility, since, despite the ADF percentage around $24 \%$, it exhibits a low percentage of lignin $(1 \%)$, which means that almost all the fiber is digested in the rumen (20). Furthermore, the improvement in ADF digestibility in this study reflects the composition of the citrus pulp, which has been considered an intermediate food between forage and concentrate (21) by improving rumen fermentation, and the higher effectiveness of fiber as compared to corn or soybeans depending on pectin (5). In addition, citrus pulp is rapidly and extensively degraded in the rumen, being its degradation higher when compared to soybeans, as the citrus pulp has a high percentage of soluble carbohydrates and pectin; which is a high rumen degradability component in the cell wall (22).

There was a significant effect $(p<0.05)$ of the energy source on the concentration of TDN, as the soybean treatment showed higher values as compared to other treatments. This was due to the greater use of TDN by animals, since the digestibility of the same was higher for animals receiving the soybean treatment in relation to all other treatments.

For the energy source effect obtained on the excretion of GE and NDF, the results were consistent with what was observed for the consumption and digestibility of these nutrients, as no significant differences for these variables were found, which confirmed once more the fact that the diets were isocaloric and had similar NDF values, indicating a fermentation profile and the constant and similar utilization of these nutrients and, therefore, no marked effect on the excretion of the same.

The increased excretion of ADF and EE for animals fed with soybeans is related to the composition of these nutrients in diets (Table 1 ), being higher for the soybean treatment in comparison with the other treatments. Similarly, such increase was also due to the higher consumption of these nutrients (Table 2) and the absence of the effect of the treatment on digestibility (Table 3 ) of these variables, which led to a lower retention and utilization of these nutrients and consequently, the increase in the excretion of the same.

On the other hand, while the citrus pulp has a lower CP percentage when compared with corn and soybeans, this protein can be even
El tratamiento con pulpa cítrica presentó mayor $(p<0.05)$ digestibilidad de la fracción de FDA, cuando fue comparado con el tratamiento control. Esto se explica, debido a que la fracción fibrosa de la pulpa cítrica presenta elevada digestibilidad ruminal, puesto que, a pesar del porcentaje de FDA en torno de $24 \%$, presenta también bajo porcentaje de lignina (1\%), lo que significa que casi la totalidad de la fibra es digerida en el rumen (20). Por otro lado, la mejora en la digestibilidad de la FDA en el presente trabajo, refleja la composición de la pulpa cítrica, la cual ha sido considerada un alimento intermediario entre forraje y concentrado (21), por la mejora en los padrones de la fermentación ruminal y por presentar una mejor efectividad de la fibra en comparación al maíz o granos de soya, en función de la pectina (5). Además, la pulpa cítrica es rápida y extensamente degradada en el rumen, siendo superior en degradación cuando es comparada con los granos de soya, debido a que la pulpa cítrica tiene un alto porcentaje de carbohidratos solubles y contiene pectina; componente de la pared celular de alta degradabilidad ruminal (22).

Hubo efecto significativo $(p<0.05)$ de la fuente energética para la concentración de NDT, presentando el tratamiento con granos de soya mayor valor en comparación a los demás tratamientos. Esto se debió al mayor grado de aprovechamiento de NDT por parte de los animales, ya que la digestibilidad de los mismos, fue mayor para los animales que recibieron el tratamiento con soya, con relación a los demás tratamientos.

Para el efecto de fuente energética obtenido, sobre la excreción de EB y FDN, los resultados coincidieron con lo observado en el consumo y en la digestibilidad de estos nutrientes, siendo que tampoco se encontraron diferencias significativas para esas variables, lo que confirmó una vez más, el hecho de que las dietas eran isocalóricas y con valores similares de FDN, indicando un perfil fermentativo y de aprovechamiento constante y similar de esos nutrientes $y$, por consiguiente, no presentando un efecto marcado sobre la excreción de los mismos.

El aumento de la excreción de FDA y de EE para los animales que consumieron soya, está relacionado con la composición de estos nutrientes en las dietas (Tabla 1), siendo mayores para el tratamiento con soya en comparación con los demás tratamientos. De igual forma, ese aumento fue debido también, al mayor consumo de estos nutrientes (Tabla 2) y la ausencia de efecto de tratamiento sobre la digestibilidad (Tabla 3) de estas variables, lo que llevó a una menor retención y aprovechamiento de estos nutrientes y consecuentemente, al aumento de la excreción de los mismos. 
less digestible, which led to an increase in the excretion of $\mathrm{CP}$ and therefore nitrogen in this experiment. Porcionato et al (23), when working with mixed bulls ( $1 / 2$ Holstein $x \quad 1 / 2$ Zebu), found lower CP digestibility coefficients as the level of citrus pulp in the diet increased. This effect is due to the high percentage of protein retained in the fibrous portion of its composition, which reflects a lower retention of nitrogenous compounds in the rumen and consequently, an increase in the excretion of the same.

In contrast, Rodrigues et al (24), when replacing corn with citrus pulp in ovine diets, found no difference in the amount of nitrogen both in feces and urine; which did not alter the nitrogen metabolism. Henrique et al (21) showed a better utilization of nitrogen in sheep when receiving citrus pulp, justified by the increase in the intake of DM with the addition of this energy source.

According to the results obtained, it is concluded that the inclusion of $15 \%$ of soybean grains in the diet of cattle reduced the consumption of $D M, C P, N F E$ and OM, while none of the sources altered the consumption of NDF, ADF, and EE. This indicates that the inclusion of citrus pulp is a satisfactory alternative to improve the intake of DM and its fractions.

A rich source of pectin, such as citrus pulp, or in unsaturated fatty acids, such soybean grains, with an inclusion of $15 \%$ in DM, was not detrimental for the digestibility of the diets, being these listed as high potential sources for use in cattle diets.

The inclusion of $5.30 \%$ of EE from unsaturated fatty acids in the diet of cattle can be carried out, since this does not cause negative effects in the apparent total digestibility of dry matter and its fractions.

The inclusion of citrus pulp proved to be efficient for reducing the excretion of certain nutrients; however, it resulted in a lower retention of nitrogenous compounds, thus increasing their excretion.

\section{Acknowledgements}

To the institutions that funded the research project, CNPq, CAPES and FAPESP, as well as to the scholarships awarded to the postgraduate learners.
Por otro lado, a pesar de que la pulpa cítrica presenta un menor porcentaje de PB cuando es comparada con el maíz y el grano de soya, esa proteína puede ser aún menos digestible, lo que llevó a un aumento de la excreción de PB y consecuentemente de nitrógeno, en el presente experimento. Porcionato et al (23), al trabajar con bovinos machos, cruzados ( $1 / 2$ Holstein X 1/2 Cebú), encontraron menores coeficientes de digestibilidad de la PB a medida que aumentaron el nivel de pulpa cítrica en la dieta. Este efecto es debido al alto porcentaje de proteína retenida en la parte fibrosa de su composición, lo que refleja una menor retención de los compuestos nitrogenados en el rumen y consecuentemente, un aumento de la excreción de los mismos.

En contraste, Rodrígues et al (24) al sustituir el maíz por pulpa cítrica en dietas para ovinos no encontraron diferencias en la cantidad de nitrógeno tanto en las heces como en la orina; lo que no alteró el metabolismo del nitrógeno. Henrique et al (21) mostraron mejor aprovechamiento del nitrógeno en ovinos recibiendo pulpa cítrica, justificado por el aumento de ingestión de MS con la adición de esta fuente energética.

De acuerdo con los resultados obtenidos, se concluye que la inclusión de $15 \%$ de soya en grano en la dieta de bovinos redujo los consumos de MS, PB, ENN y MO. Entre tanto, ninguna de las fuentes alteró el consumo de FDN, FDA, y EE. Esto indica que la inclusión de pulpa cítrica es una alternativa satisfactoria para mejorar el consumo de MS y sus fracciones.

Una fuente rica en pectina, como la pulpa cítrica, o en ácidos grasos insaturados, como el grano de soya, con una inclusión de $15 \%$ en la MS, no perjudicaron la digestibilidad de las dietas, siendo indicadas como fuentes de elevado potencial de uso en dietas para bovinos.

La inclusión de $5.30 \%$ de EE proveniente de ácidos grasos insaturados, en la dieta de bovinos, puede realizarse, debido a que no provocan efectos negativos en la digestibilidad aparente total de la materia seca y sus fracciones.

La inclusión de pulpa cítrica se mostró eficiente para reducir la excreción de algunos nutrientes; sin embargo, insidió en una menor retención de los compuestos nitrogenados, aumentando de esta forma su excreción.

\section{Agradecimientos}

A las entidades financiadoras del proyecto de investigación, CNPq, CAPES y FAPESP, así como también por las becas otorgadas a los discentes de pos-graduación. 


\section{REFERENCES}

1. Véras RML, Ferreira MA, Cavalcanti CVA, Véras ASC, Carvalho FFR, Santos GRA, et al. Substituição do milho por farelo de palma forrageira em dietas de ovinos em crescimento. Desempenho. R Bras Zootec 2005; 34:249-256.

2. Fayed AM, El-Ashry MA, Hend AA. Effect of feeding olive tree pruning by-products on sheep performance in Sinai. World J Agric Sci 2009; 5(4):436-445.

3. Van Soest PJ. Nutritional ecology of the ruminant. 2. ed. New York: Cornell University Press; 1994.

4. Nogueira KA, Valinote AC, Nogueira Filho JCM, Leme PR, Silva SL. Substituição do milho pela polpa de citros em dietas com alta proporção de concentrado sobre a degradabilidade e cinética ruminal. Acta Sci Anim Sc 2009; 31(2):155-160.

5. Eifert EC, Lana RP, Lanna DPD, Leopoldino WM, Oliveira MVM, Arcuri PB, et al. Consumo, produção e composição do leite de vacas alimentadas com óleo de soja e diferentes fontes de carboidratos na dieta. R Bras Zootec 2006; 35(1):211-218.

6. Association of Official Analytical Chemists. AOAC. Official methods of analyses. $18^{\text {th }}$ ed. Gaithersburg MD, USA: AOAC; 2005.

7. Bateman JV. Nutrición animal. Manual de métodos analíticos. Primera edición en español. México: Herrero Hermanos, Sucesores, S.A.; 1970.

8. Conceição $D$, Jacques $R$, Bento $F$, Simonetti A, Selbach P, Camargo F. Redução de cromo hexavalente por bactérias isoladas de solos contaminados com cromo. Cienc Rural 2007; 37(6):1661-1667.

9. NRC. National Research Council. Nutrients requirements of dairy cattle. 7.ed. Washington, D.C.: National Academy Press; 2001.

10. SAS. Statistical Analysis System [CD-ROM]. Versión 9.2. Cary, NC, USA: SAS Inst, Inc; 2010.

11. Calsamiglia S, Bach A, Blas C, Fernández C, García-Rebollar p. Necesidades nutricionales para rumiantes de leche: Normas FEDNA. Madrid: Peninsular SL; 2009.
12. Bassi MS, Ladeira MM, Chizzotti ML, Chizzotti FHM, Oliveira DM, Neto ORM, et al. Grãos de oleaginosas na alimentação de novilhos zebuínos: consumo, digestibilidade e desempenho. R Bras Zootec 2012; 41(2):353-359.

13. Harvatine $\mathrm{KJ}$, Allen MS. The effect of production level on feed intake, milk yield, and endocrine responses to two fatty acid supplements in lactating cows. J Dairy Sci 2005; 88:4018-4027.

14. López SE, López J. Suplementação lipídica para vacas leiteiras. Pesq Agrop Gaúcha, Porto Alegre. 2005; 11(2):103-112.

15. Oliveira JS, Zanine AM, Santos EM. Diversidade microbiana no ecossistema ruminal. REDVET [Revista en internet] 2007. [acceso 23 de agosto de 2012]; 8(6). Disponible en: http://www. veterinaria.org/revistas/redvet/n060607.html

16. Forbes JM. Voluntary food intake and diet selection in farm animals. $2^{\mathrm{a}}$ ed. London, UK: CAB International; 2007.

17. Oliveira RL, Assunção DMP, Barbosa MAAF, Ladeira MM, Silva MMP, Mascarenhas AG, et al. Efeito do fornecimento de diferentes fontes de lipídeos na dieta sobre o consumo, a digestibilidade e o $\mathrm{N}$-uréico plasmático de novilhos bubalinos em confinamento. R Bras Zootec 2007; 36:733-738.

18. Leite, LC. Perfil dos ácidos graxos do leite e metabolismo de lipídios no rúmen de vacas recebendo dietas com alto ou baixo teor de concentrado e óleo de soya ou de peixe [Tesis doctoral]. Piracicaba, São Paulo: Universidade de São Paulo, Escola Superior de Agricultura "Luiz de Queiroz"; 2006.

19. Harvatine KJ, Allen MS. Effects of fatty acid supplements on milk yield and energy balance of lactating dairy cows. J Dairy Sci 2006; 89:1081-1091.

20. Marino CT, Otero WG, Rodrigues PHM, Dicostanzo A, Millen DD, Pacheco RLD, et al. Effects of adding polyclonal antibody preparations on ruminal fermentation patterns and digestibility of cows fed different energy sources. J Anim Sci 2011; 89:3228-3235. 
21. Henrique $W$, Sampaio AAM, Leme PR, Alleoni GF, Lanna DPD, Malheiros EB. Digestibilidade e Balanço de Nitrogênio em Ovinos Alimentados à Base de Dietas com Elevado Teor de Concentrado e Níveis Crescentes de Polpa Cítrica Peletizada. R Bras Zootec 2003; 32(6 Supl 2):2007-2015.

22. Scoton RA. Substituição do milho moído por polpa cítrica peletizada e/ou raspa de mandioca na dieta de vacas leiteiras em final de lactação [Tesis doctoral]. Piracicaba, São Paulo: Universidade de São Paulo, Escola Superior de Agricultura "Luiz de Queiroz"; 2003.
23. Porcionato MAF, Berchielli TT, Franco GL, Andrade P, Silveira RN, Soares WVB. Digestibilidade, degradabilidade e concentração amoniacal no rúmen de bovinos alimentados com polpa cítrica peletizada normal ou queimada. R Bras Zootec 2004; 33(1):258-266.

24. Rodrigues $\mathrm{GH}$, Susin I, Pires AV, Mendes CQ, Araujo RC, Packer IU, et al. Substituição do milho por polpa cítrica em rações com alta proporção de concentrado para cordeiros confinados. Cienc Rural 2008; 38(3):789-794. 